\title{
An overview of maritime pine private non-industrial forest in the centre of Portugal: A 19-year case study
}

\author{
Cristina Alegria $\bowtie$, Maria Canavarro Teixeira
}

Centro de Estudos de Recursos Naturais, Ambiente e Sociedade (CERNAS), Instituto Politécnico de Castelo Branco, Escola Superior Agrária, Unidade Departamental de Recursos Naturais e Desenvolvimento Sustentável, Apartado 119, 6001-909, Castelo Branco, Portugal, e-mail: crisalegria@ipcb.pt

\begin{abstract}
Portuguese national policies for forests were developed considering related themes such as climate change, forest health, fire and the protective functions of forests. In Portugal, maritime pine forest is mainly private non-industrial and its area is in decline. Therefore, the aim of this study was two-fold: first, to assess maritime pine forest characteristics over a 19-year period; second, to analyse forest cover change over that period. In the end, the implementation of state policies was explored. A study area highly forested by continuous areas of naturally regenerated maritime pine in the centre of Portugal was used. To assess maritime pine forest characteristics, two sets of inventory data collected in previous studies (1991-1996 and 2007-2010) were used. To analyse forest cover change, the official land cover maps for 1990 and 2007 were used. This study findings highlighted that study area's trends over the past years were the following: first, the decrease of maritime pine forest areas and its management decline (stands less stable, under-stocked, with large amounts of small-diameter poles and enlarged tree size variability); second, the increase of scrubland areas; third, the increase of eucalyptus afforestation with no regard for protection areas; and fourth, the absence of native oaks or introduction of other broadleaves as recommended by the state policies. Therefore, it is argued that there is a need for effective field monitoring actions with regard to the implementation of state policies. Additionally, selective incentives are key to mobilise private non-industrial forest to achieve the goals of state forest policies.
\end{abstract}

\section{KeY WORDS}

annual burnt areas, eucalyptus afforestation, national goals for forests, maritime pine, natural regeneration, slenderness ratio, stand stability, alien tree species

\section{INTRODUCTION}

Policies concerning forests are evolving rapidly and being implemented in all Mediterranean countries. Almost every country has national policies for forests and is creating them on related themes such as climate change, forest health, fire and the protective functions of forests (FAO 2013). In Portugal, the national policy law for forests was published in 1996 and an important legal framework was developed to support forest area management (e.g. regional forest management plans, forest management plans, forest fire protection plans and forest intervention zones). The Portuguese national strategy for forests, setting clear directions and management priorities over time, was only published in 2006 and recently updated (DR 2006a; DR 2015a). 
At the present, Portuguese forest area (34\%; 3.2 million ha) is mainly composed of eucalyptus (Eucalyptus sp.; $812 \times 10^{3}$ ha; 26\%), cork oak (Quercus suber L.; $737 \times 10^{3}$ ha; $23 \%$ ), maritime pine (Pinus pinaster Aiton; $714 \times 10^{3}$ ha; $23 \%$ ), and holm oak (Quercus rotundifolia Lam.; $331 \times 10^{3}$ ha; $11 \%$ ). The remaining forest area is occupied by other oaks (e.g. Quercus pyrenaica Willd., Quercus faginea Lam. and Quercus robur L.), umbrella pine (Pinus pinea L.), chestnut (Castanea sativa Mill.), acacia (Acacia sp.), other broadleaves and other coniferous trees (ICNF, 2013).

Portuguese forest landownership is mainly private non-industrial (74\%) and around 50\% of Portuguese forest areas have no rural register (at the centre and north of the country) (Coelho 2003; DR 2015a). Moreover, around $26 \%$ of private forest areas are less than five hectares, comprising $60 \%$ of the private forest owners and are dominated by the species maritime pine. Usually no financial investment and management are applied to this maritime pine forest. The remaining private forest area is either dominated by the species eucalyptus (areas between 5 and 100 hectares - comprising 19\% of private area and $24 \%$ of the private forest owners) or by native oaks (areas larger than 20 ha - comprising 50\% of private area and $15 \%$ of the private forest owners). In these forests, some financial investment and management are applied namely in industrial areas belonging to the pulp and paper industry in Portugal (Baptista and Santos 2005; CELPA 2014; DR 2015a).

To respond to these important constraints for forest management, Portugal followed the same trend as other European countries (Lönnstedt 2014; Sarvašová et al. 2014) by developing forest owners associations (FOA) since the 1990s. These FOAs have played an important role in supporting the constitution of forest intervention zones (ZIF). The aim of ZIFs is mobilising small private forest owners towards a common forest management plan and forest fire protection plan for sustainable forest management and fire hazard mitigation while rural register will be produced. At the present, 177 FOAs are registered and 165 ZIFs have been created wherein $84 \%$ of these FAOs and $68 \%$ of these ZIFs are located at the centre and north of the country.

In 1980-1989, maritime pine was the dominant species (1.3 milion ha; $40 \%$ ) of Portuguese forest (AFN 2010) as a result of the national afforestation plan (1938-1977) that favoured the expansion of this species
(Mendes 2007; Jones et al. 2011). In the 1970s, due to both socio-economic and demographic factors (e.g. rural desertification and farmers ageing), maritime pine forest management for domestic use has started to decline and these areas became more vulnerable to forest fires (Fidalgo and Páscoa 2012). Consequently, this species area began to decrease from $978 \times 10^{3}$ ha in 1995 , to $795 \times 10^{3}$ ha in 2005 and to $714 \times 10^{3}$ ha in 2010 . In addition, in 1999, the presence of the wilt disease caused by the pine wood nematode (Bursaphelenchus xylophilus) was first reported in Portugal (at Setúbal's peninsula) and has progressed to the centre of the country since 2008 (AFN 2012; Sukovata et al. 2012). This situation imposes the need of official authorisation for coniferous harvesting, pruning and wood circulation (AFN 2012). As a result, the majority of maritime pine area has been changing to "scrubland and pastures" $\left(165 \times 10^{3} \mathrm{ha}\right)$ and to eucalyptus forest $\left(70 \times 10^{3} \mathrm{ha}\right)$ (ICNF 2013). Even so, it is at the centre of the country that maritime pine stands are still largely located $\left(607 \times 10^{3}\right.$ ha; 60\%) (AFN 2010).

Eucalyptus is an alien species that has been introduced in Portugal for more than 200 years but it was only since the 1990s that this species area has greatly increased from $386 \times 10^{3}$ in $1980-1989$ to $717 \times 10^{3}$ ha in $1995,787 \times 10^{3}$ ha in 2005 and $812 \times 10^{3}$ ha in 2010 (Silva et al. 2007; AFN 2010). In fact, during the past 20-30 years, private non-industrial forest owners have chosen this species to convert its maritime pine forest (Fidalgo and Páscoa 2012) as both species have the same ecological suitability areas (Sub-Atlantic, Sub-Atlantic, Atlantic-Mediterranean and Sub-Mediterranean) (Albuquerque 1954; Dias et al. 2008; Alves et al. 2012). This species is explored in short harvesting cycles (e.g. three rotations of 10-12 years each) to supply the national wood market for pulp and paper industry in Portugal. Furthermore, more than $50 \%$ of eucalyptus wood used in this industry is provided by the national market (CELPA 2014). However, studies about eucalyptus afforestation have reported effects on soil, water, biodiversity and ecosystem functioning due to this species' invasive behaviour and fire hazard, which may lead to irreversible environmental impacts in the future (Silva et al. 2007).

In that view, the Portuguese national strategy for forests recommends, as a goal for forest composition in 2030, that eucalyptus area will not increase as oppo- 
sed to the others species of Portuguese forest for which an increase is expected as follows: maritime pine ( $P i$ nus pinaster Aiton) $+2-11 \%$; umbrella pine (Pinus pinea $\mathrm{L}$.) $+15-32 \%$, other coniferous $+10-56 \%$, cork oak (Quercus suber L.) $+1-13 \%$, holm oak (Quercus rotundifolia Lam.) $+0-5 \%$, others oaks (e.g. Quercus pyrenaica Willd., Quercus faginea Lam. and Quercus robur L.) $+10-40 \%$, chestnut (Castanea sativa Mill.) $+17-42 \%$ and other broadleaves $+11-22 \%$ (ICNF 2015).

Therefore, the aim of this study was two-fold: first, to assess maritime pine forest characteristics over a 19-year period; second, to analyse forest cover change over the same period. A study area highly forested by continuous areas of naturally regenerated maritime pine in the centre of Portugal was used. To assess private non-industrial maritime pine forest characteristics, two sets of inventory data collected in previous studies (1991-1996 and 2007-2010) were used. To analyse forest cover change, the official land cover maps for 1990 and 2007 were used. In the end, the implementation of state policies was explored.

\section{Material AND METHOdS}

\section{Study area}

The study area is located at the centre of Portugal in a municipality highly forested by continuous areas of naturally regenerated maritime pine, the municipality of Oleiros (Fig. 1A, B). In 1995, 71\% of this municipality $(47,109 \mathrm{ha})$ was occupied by forested area $(33,100 \mathrm{ha})$ where maritime pine (27,700 ha; $84 \%$ ) was the dominant species (DGF 2001). However, between 1990 and 2009, this municipality's maritime pine forest was severely devastated by forest fires. An average area of 2,665 ha per year were burnt (ranging from a minimum of 3 ha in 2007 to a maximum of 19,765 ha in 2003) (Fig. 1B). The wildfire in 2003 was the most severe one and accounted for around $50 \%$ of the total burnt area over the period under analysis.

Likewise in 1990, the locality of Sarnadas S. Simão (Fig 1C; 3,100 ha), our study area, was extensively occupied by continuous areas of maritime pine $(2,410$ ha; $78 \%$ ) and was severely devastated by the wildfire in 2003 (1,516 ha; 49\%). In spite of that, the study area
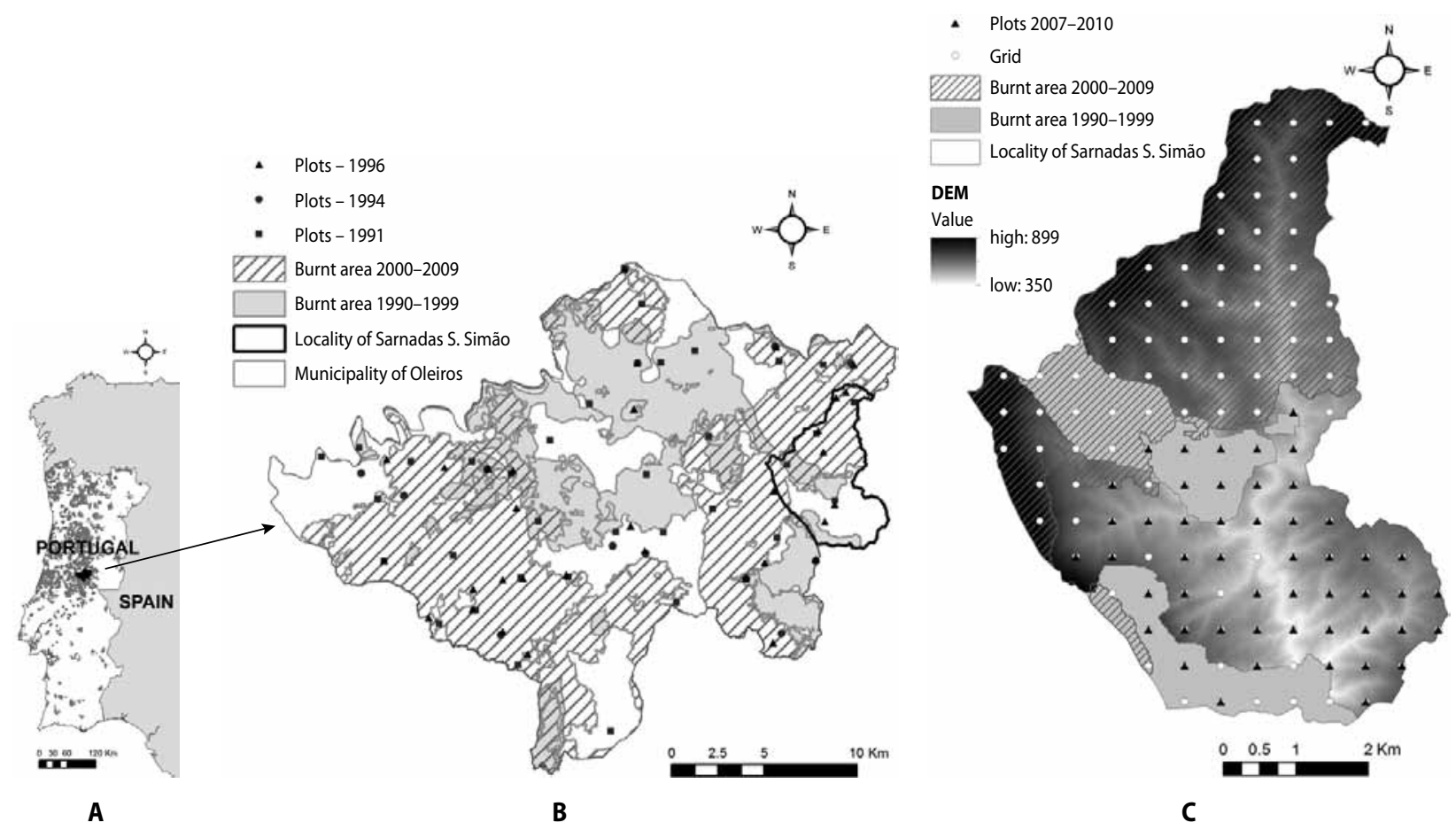

Figure 1. Study area: A - maritime pine distribution in 2005 (Godinho-Ferreira et al. 2005) and the municipality of Oleiros; B - municipality of Oleiros and its locality of Sarnadas S. Simão - burnt area (1990-2009) (ICNF 2015) and sample plots in 1991, 1994 and 1996; C - locality of Sarnadas S. Simão - burnt area (1990-2009) (ICNF 2015) and sample plots in 2007 and 2010 
was still dominated by maritime pine forest in 2007 (1,822 ha; 59\%), with mature stands at the south and young regenerate stands at the north. The study area has also the peculiarity of having a vast protection area (1,822 ha; 59\%) (DR 2015b). Additionally, the mountain area at the West (Serra do Moradal) is included at the Geopark of „Naturtejo da Meseta Meridional”, which is integrated into UNESCO World Geoparks since 2006.

According to the Regional Forest Management Plan, in which the area under study is included, the following goals are recommended to be achieved in 2025 for forest area composition: $75 \%$ of maritime pine, $2 \%$ of cork oak, $15 \%$ of eucalyptus, $11 \%$ of Pyrenean oak, $1 \%$ of chestnut and $1 \%$ of other broadleaves (DR 2006b).

\section{Maritime pine inventory data}

In 1991, 1994 and 1996, 76 circular plots of $500 \mathrm{~m}^{2}$ of area were installed over this municipality (Fig. 1B), wherein the study area is included (9 plots), to study private non-industrial maritime pine forest characteristics (Carvalho 1992; Almeida 1994; Alegria and Tomé 2013). A systematic sampling was used to install the plots in 1991 and 1994. While in 1996, based on the data previously collected, a stratified sampling in accordance with growth variability conditions, with respect to stand development stage, site productivity and stand density was used. In each plot, the diameter at breast height $(d)$ was measured for all trees taller than $5 \mathrm{~cm}$. Tree total height $(h)$ was measured in a subset of trees (sample trees) proportionally selected to the diameter class frequency in each sample plot both in 1991 and 1994 as opposed to 1996 where all tree total heights were measured. Tree age $(t)$ was also evaluated using an increment borer in a subset of trees in each plot, as follows: a dominant tree, a co-dominant and a dominated tree in 1991; one tree per diameter class in 1994; and two trees per diameter class and/or a minimum of ten trees per plot in 1996. However, between 1990 and 2009, due to fire occurrence $75 \%$ of these inventory plots were burnt, wherein $77 \%$ of them were burnt during the wildfire in 2003 (Fig. 1B).

In 2007 and 2010, further studies in private non-industrial maritime pine forest (Martins 2007; Mestre 2011) were performed in the study area (Fig. 1C) where 50 circular plots of $500 \mathrm{~m}^{2}$ of area were installed. A systematic sampling supported by a geo-referenced $500 \mathrm{~m}$ spacing grid was used to install these plots. Due to the wildfire in 2003, mature maritime pine stands could only be found in the southern zone of this locality (Fig. 1C). The northern zone was covered either by young naturally regenerated maritime pine stands that were too small to be measured (18 plots) or by scrubland (13 plots). In each plot, the same data collection procedures as those in 1994 were used. However, no tree age data were collected.

To assess private non-industrial maritime pine stands characteristics over time, these two sets of inventory data collected in the study area, the locality of Sarnadas S. Simão, in previous studies (1991-1996 and 2007-2010) were used. The natural regeneration of species was analysed using the plots located over the northern zone of study area that was burnt in 2003's wildfire.

\section{Maritime pine stands and evaluation of tree variables}

The data collected, both in the municipality of Oleiros and in the study area, the locality of Sarnadas S. Simão, allowed for an overall characterisation of maritime pine stands' stability, density and stocking, site productivity and volume. The standard stand variables (Tab. 1) considered were the following: $N$, number of trees per hectare (trees ha $\left.{ }^{-1}\right) ; G$, basal area per hectare $\left(\mathrm{m}^{2} \mathrm{ha}^{-1}\right) ; d g$, quadratic mean diameter $(\mathrm{cm}) ; \bar{h}$, mean height (m); $h / d$, stand slenderness ratio; ddom, dominant diameter $(\mathrm{cm})$ and hdom, dominant height (m) (e.g. Loetsch et al. 1973; Husch et al. 1982; Avery and Burkhart 1983). Stand slenderness ratio $(h / d)$ was evaluated as the average of individual tree values (using both variables in the same units). Stand stability (Tab. 1) was evaluated according to Becquey and Riou-Nivert (1987) as the stand slenderness ratio $(h / d)$ against stand dominant height to classify stands according to the following three stability classes: stable, moderately stable and unstable. Stand stability is primarily a function of stand spacing and is usually used to support thinning schedules by assessing stand resistance to wind throw or snow breakage conditions (e.g. Castedo-Dorado et al. 2009; Martin-Alcon et al. 2010). However, in this study, the analysis of stand stability was used to have an insight about stand growth conditions with regard to stand density and stocking. In fact, it is known that the average height of the stand may be changed by thinning, depending on the thinning method, but within wide limits of stand density. 
In opposition, spacing experiments have shown that denser stands of equal dominant height often have trees of smaller diameters than less denser stands as the- re is a negative correlation between stand density and average stand diameter (Clutter et al. 1983; Davis and Johnson 1987).

Table 1. Summary statistics for stand and tree variables: municipality of Oleiros (plots in 1991, 1994 and 1996; $n=76$ ) and study area, the locality of Sarnadas S. Simão (plots in 2007 and 2010; $n=50$ )

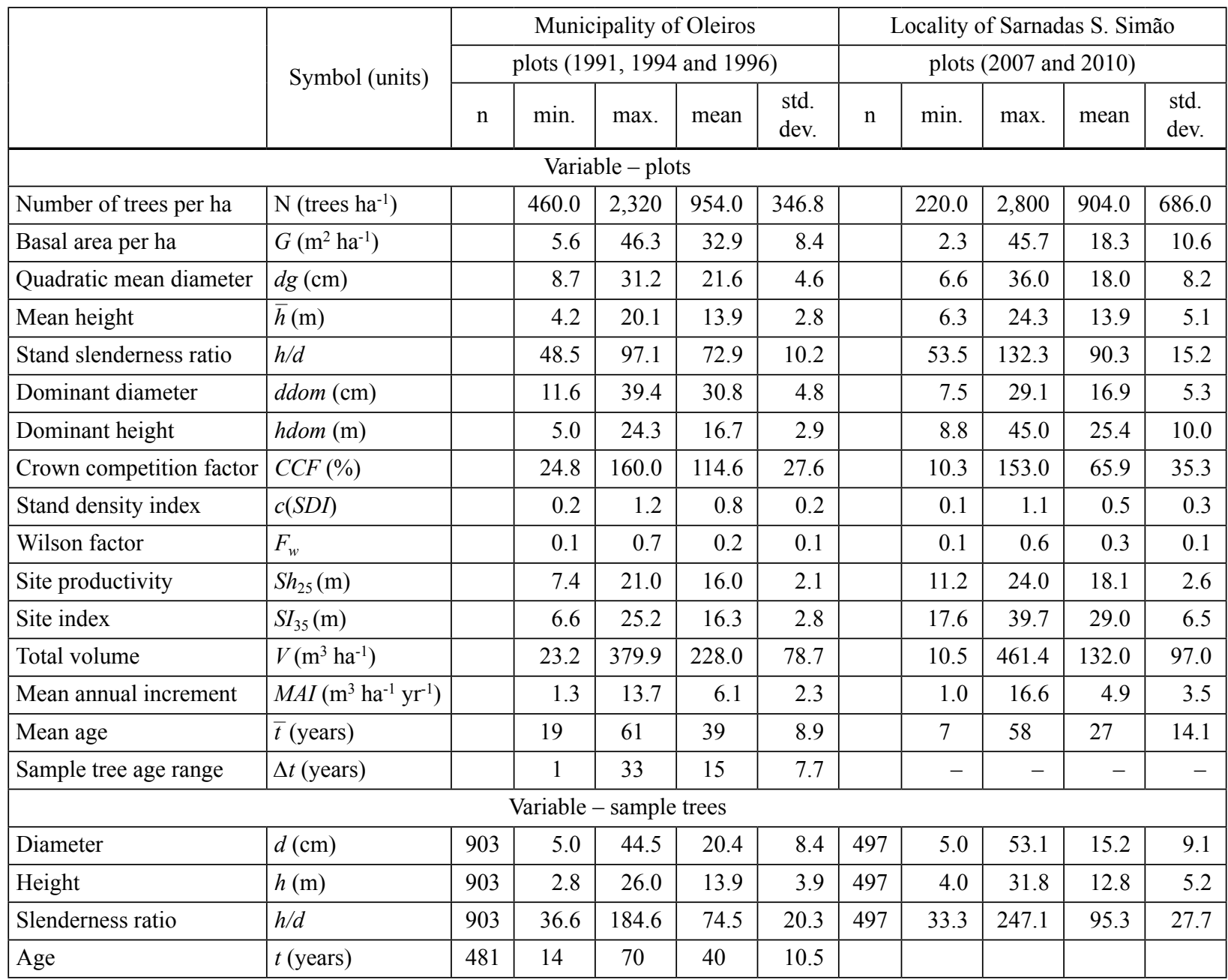

$n$-sample size; min. - minimum; max. - maximum; std. dev. - standard deviation

Stand stocking (Tab. 1) was assessed using the following indices: $C C F$, crown competition factor (\%); $S D I$, stand density index and $F_{w}$, Wilson's factor (Reineke 1933; Wilson 1946; Krajicek et al. 1961; Clutter et al. 1983; Davis and Johnson 1987). The crown competition factor $(C C F)$, fitted for the species in the centre inland region of Portugal (Alegria 2011a), allowed for plot's stocking assessment (Appendix 1: Eq. 1). A $C C F$ value of $100 \%$ indicates that the minimum density below that site is under-stocked, while values higher than $100 \%$ in- dicate that intra-specific competition starts to get more intense (Husch et al. 1982; Clutter et al. 1983). Additionally, the stand density index (SDI), fitted by Luís et al. (1991) for maritime pine stands in Portugal, was used to evaluate the need for thinning by using the following stocking classes (Appendix 1: Eq. 2) to be assessed:

- over-stocked $(c(S D I)>1)$ - thinning needed;

- fully-stocked $(c(S D I) \in] 0.58,1])$ - thinning needed;

- under-stocked $(c(S D I) \in] 0.26,0.58])$ - may require future thinning; 
- very under-stocked $(c(S D I) \leq 0.26)$ - no need for intervention.

These two last density indices, $C C F$ and $c(S D I)$, are strongly positively correlated $(r=0.99)$ and as a result a $C C F=100 \%$ corresponds to a $c(S D I)=0.78$ (fully stocked).

Wilson's factor for stand irregular spacing was also evaluated (Appendix 1: Eq. 3) as it is a density index widely used in Portugal. Wilson's factors of 0.11, 0.16, $0.20,0.23$ and 0.28 correspond, respectively, to the thinning grades A (natural mortality), C (light thinning), C/D, D and E (heavy thinning) (Alves 1975).

Site productivity was assessed using a height index model $\left(S h_{25}\right)$ (Clutter et al. 1983; Huang and Titus 1993; Vanclay 1994) developed for both these species type of stands and the study area (Alegria and Tomé 2013). The $S h_{25}$ index (Appendix 1: Eq. 4), also called site form by Vanclay (1994), is defined as the expected tree height at the reference diameter of $25 \mathrm{~cm}$ and was computed as the average of the individual tree values. This $S h_{25}$ index is positively correlated $(r=0.85)$ with the classical site index $S I_{35}$ fitted by Páscoa et al. (1989) for Portuguese maritime pine (Appendix 1: Eq. 5). However, the $S h_{25}$ index has the advantage of not requiring age data in contrast to the site index $S_{35}$. Three site productivity classes were considered for plot classification: poor $-S h_{25}<14 \mathrm{~m}$, medium $-S h_{25} \in\left[15,16\left[\mathrm{~m}\right.\right.$ and high $-S h_{25} \geq 16 \mathrm{~m}$. The following correspondence between $S h_{25}$ and the mean annual increment of stand total volume at the rotation age of 45 years $\left(M A I_{45}\right)$ was observed: for $S h_{25}=13$ a $M A I_{45}=$ $=5 \mathrm{~m}^{3} \mathrm{ha}^{-1} \mathrm{yr}^{-1}$, for $S h_{25}=15$ a $M A I_{45}=7 \mathrm{~m}^{3} \mathrm{ha}^{-1} \mathrm{yr}^{-1}$ and for $S h_{25}=17$ a $M A I_{45}=9 \mathrm{~m}^{3} \mathrm{ha}^{-1} \mathrm{yr}^{-1}$ (Alegria, 2011a).

Stand total volume was simulated using a tree total height equation (Appendix 1: Eq. 6) and a tree total volume equation over bark (Appendix 1: Eq. 7) fitted for both these species type of stands and the study area (Alegria 2011b). Then, stand total volume was obtained as the sum of individual values, and expanded to the hectare. After which, the mean annual increment (MAI) of stand volume was assessed.

Additionally, stand diameter distributions were analysed for each of the following stand mean age classes: $\bar{t} \leq 10$ years, $\bar{t} \in$ ]10-20] years, $\bar{t} \in$ ]20-30] years, $\bar{t} \in$ ]30-40] years and $\bar{t}>40$ years. Diameter classes were organized in a range of $5 \mathrm{~cm}$ considering the initial class as $[2.5,7.5[\mathrm{~cm}$. Finally, sample trees data (Tab. 1) were used to analyse tree slenderness ratio $(h / d)$ in order to allow having an insight about stands growth conditions regarding to stand density and stocking. In addition, sample trees age data collected in 1991, 1994 and 1996 allowed for the analysis of stand structure (Tab. 1).

\section{Maritime pine stands and tree characteristics analysis}

The data collected during 1991, 1994 and 1996 over the study area, the locality of Sarnadas S. Simão $(n=9)$, were first compared to the rest of the data collected over the municipality of Oleiros $(n=76-9=67)$ to prove that study area's data were not statistically different from the rest of the municipality's data in respect to the variables in Table 1. The data collected over the study area in 1991, 1994 and 1996 (Fig. 1B) were compared to the data collected in 2007 and 2010 (Fig. 1C) to prove that they were statistically different in respect to the variables in Table 1. The Student's $t$-test for independent samples was used to find if there were significant statistical differences between data samples. The assumptions of data normality and of homogeneity of variances were verified using respectively, the Kolmogorov-Smirnov test or the Shapiro-Wilk test (small samples) and the Levene Statistic (Maroco 2011). An analysis of stand and tree characteristics was performed for the data collected in 1991, 1994 and 1996 both at the municipality scale $(n=76-9=67$; Fig. 1B) and at the locality scale ( $n=9$; Fig. 1B). The same analysis was performed for the data collected in 2007 and 2010 at the locality scale ( $n=50$; Fig. 1C) followed by an analysis over time (1991-1996 vs. 2007-2010).

Stand diameter distributions were obtained to analyse small-diameter poles (e.g. $d \leq 12.5 \mathrm{~cm}$ ) and to investigate thinning practice by using a test of independency Chi-Square $\left(\mathrm{c}^{2}\right)$ with regard to stand mean age class and stand stability.

Finally, sample tree size variability within each plot (e.g. diameter and height standard deviations) was assessed by the coefficient of variation (CV) of 1991-1996 plots and of the 2007-2010 plots. Sample trees slenderness ratio (Tab. 1) was analysed with regard to stand stability class. Then, small-diameter poles (e.g. $d \leq 12.5 \mathrm{~cm})$ slenderness ratio was further analysed. A Student's $t$-test for independent samples was used when there were only two stand stability classes under analysis. Both assumptions of data normality and of homogeneity of variances were verified. While an $F$-test (ANOVA) was used in case of three stand stability clas- 
ses under analysis and after applying the Tukey test for multiple comparisons. Despite the data not following a normal distribution, the sample was large enough to allow for the use of a parametric test (Maroco 2011).

To assess maritime pine natural regeneration after the occurrence of the 2003 wildfire over the northern zone of study area (18 plots in 2007), the following variables were evaluated regarding if seedlings mean height (m) was higher than $1.30 \mathrm{~m}$ (tall regeneration) or not (short regeneration): $G C$, ground cover (\%); $N_{\mathrm{s}}$, number of seedlings per hectare (seedlings ha ${ }^{-1}$ ); and $\bar{t}_{s}$ and seedlings mean age (years).

\section{Forest cover change (1990-2007)}

The study area's land cover change during the period of 1990-2007 was performed using the national land cover maps for 1990 (DGT 2015a) and 2007 (DGT 2015b) to evaluate the gains and losses of forest land cover classes over the study area. These maps are produced at a 1:25,000 scale, using a minimum mapping unit of 1 ha and a five-level classification system of 238 land cover classes.

The land cover classes observed and considered for analysis were the following: 'Artificial surfaces', 'Agricultural areas', 'Cork oak forest', 'Oak forest', 'Eucalyptus forest', 'Broad-leaved forest', 'Maritime pine forest', 'Maritime pine and eucalyptus mixed forest', 'Natural grasslands', 'Moors and heathland', 'Sclerophyllous vegetation', 'Cork oak open forest', 'Eucalyptus open forest', 'Maritime pine open forest', 'Eucalyptus and coniferous open mixed forest', 'Maritime pine and broad-leaved open mixed forest', 'Other woodland', 'Cuts', 'New plantations', 'Beaches, dunes, sands', 'Bare rocks', 'Sparsely vegetated areas', 'Burnt areas' and 'Water bodies'. Forests are classified as 'forests' when $G C$ is greater than $30 \%$ and as 'open forests' when the $G C$ ranges from $10 \%$ to $30 \%$. Land cover classes areas were evaluated using ArcGIS 10.1 software (ESRI 2010) and after classes gains and losses were assessed.

\section{Results}

\section{Maritime pine stands in 1991-1996}

The plots installed in 1991, 1994 and 1996 were either classified as stable or as moderately stable (Fig. 2A). Stocking assessment according to the $C C F$ values indi- cate that about $23 \%$ of the stands have values over $100 \%$, which means that intra-specific competition is already being experienced to some degree. When considering the observed values of $c(S D I)$ index, it can be pointed out that about $90 \%$ of the stands were fully stocked or over-stocked, needing an appropriate thinning schedule according to stand stability (Fig. 2B-C). Moderately stable plots were mainly found in high productivity sites conversely to stable plots (Fig. 2D). Higher stand total volume per hectare was also observed in moderately stable plots compared to stable plots (Fig. 2E).

Analysing plots' diameter distributions (Fig. 2F-G), it can be seen that there are always small-diameter poles (e.g. $d \leq 12.5 \mathrm{~cm}$ ) even in older stands. The occurrence of small-diameter poles was found dependent of both age class and stability class $\left(\mathrm{c}^{2}(3)=893.100, p\right.$-value $=0.000)$, with larger incidence in both stable stands and age class of $\bar{t} \in] 10,20]$ years, followed by both moderately stable stands and age class of $\bar{t} \in] 20,30]$ years.

The coefficient of variation $(\mathrm{CV})$ of plot tree size variability was $25 \%$ for tree diameter variability and $35 \%$ for tree height variability. Sample trees slenderness ratios $(h / d)$ (Fig. $2 \mathrm{H})$ were found statistically different with regard to stand stability $(F(2,50)=6.197$, $p$-value $=0.004)$. Sample tree slenderness ratios $(h / d)$ were higher in moderately stable stands than in stable stands $(t(761)=10.104, p$-value $=0.000)$. With regard to small-diameter poles (e.g. $d \leq 12.5 \mathrm{~cm}$ ), the slenderness ratios $(h / d)$ were found to be higher in moderately stable stands $(h / d=111.10)$ than in stable stands $(h / d=88.67)$.

Additionally, the analysis of sample tree age data proved that the vast majority of these plots have multi-aged structures due to natural regeneration (e.g. average stand tree age variation of 15 years) (Fig. 2I-J).

\section{Maritime pine stands in 2007-2010}

The plots installed in 2007 and 2010 were either classified as moderately stable or as unstable (Fig. 3A). Plots' stocking was quite variable. However, about $60 \%$ of the stands were under-stocked or very under-stocked (Fig. 3B-C). Unstable plots were mainly found in higher productivity sites (Fig. 3D). However, higher stand total volume per hectare was not always observed in unstable plots due to inadequate stocking (Fig. 3E).

On analysing plots' diameter distributions, it was once more observed that there are always small-diameter poles (e.g. $d \leq 12.5 \mathrm{~cm}$ ) even in older stands 
A

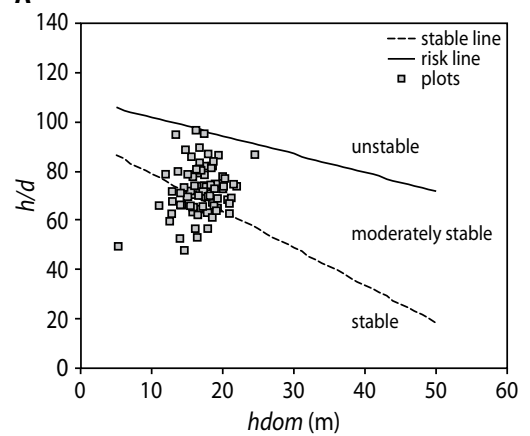

D

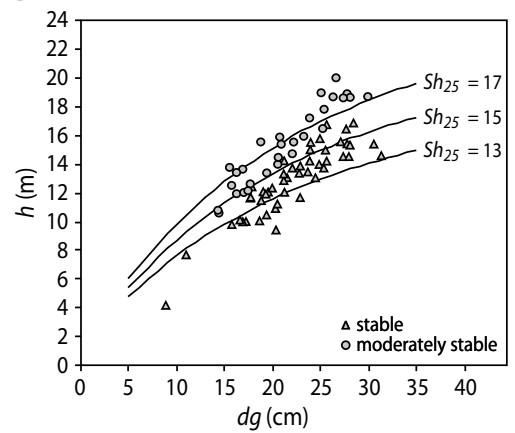

F

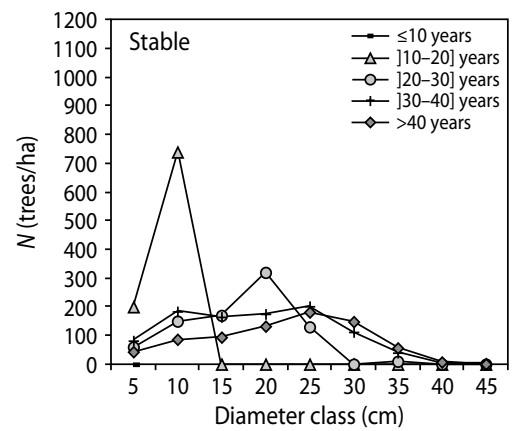

B

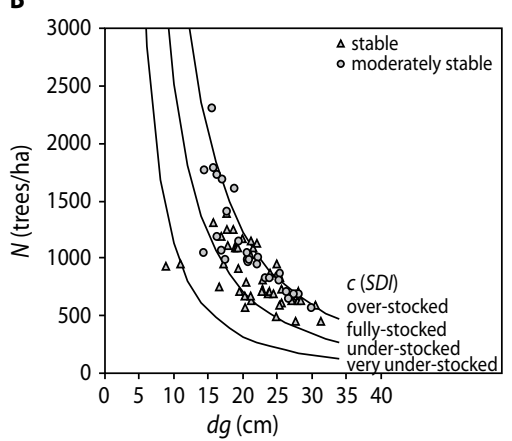

E

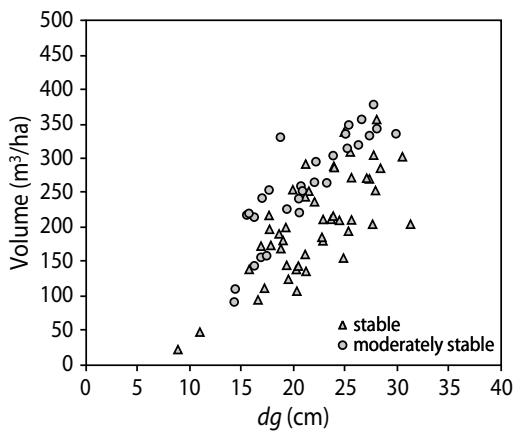

G

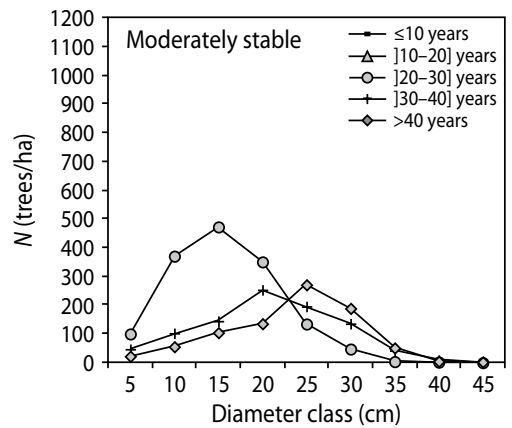

C

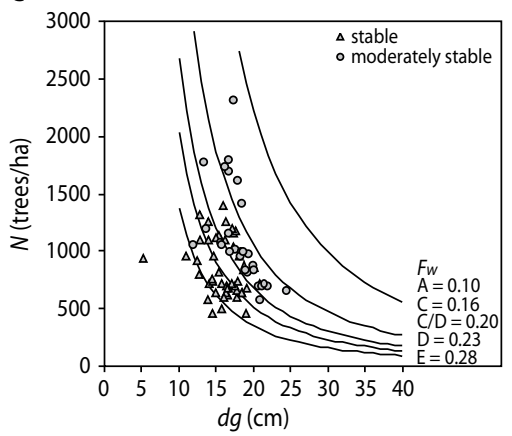

-
I

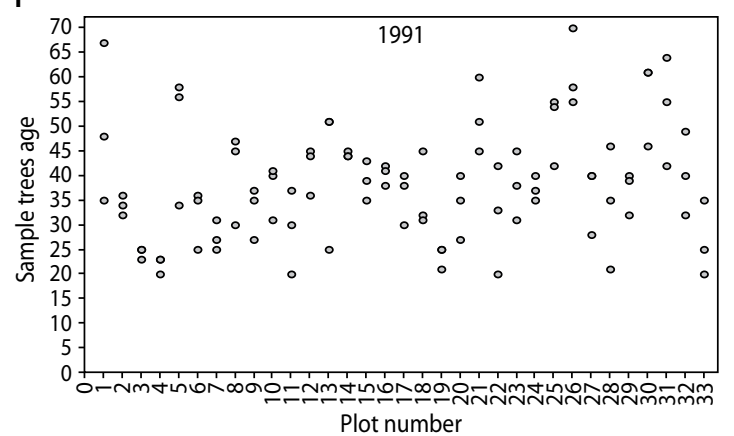

J

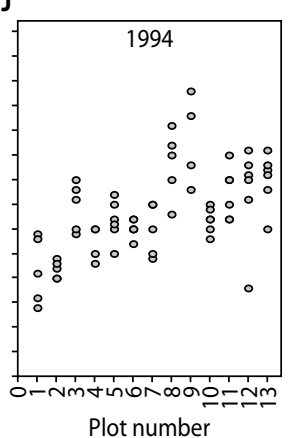

H

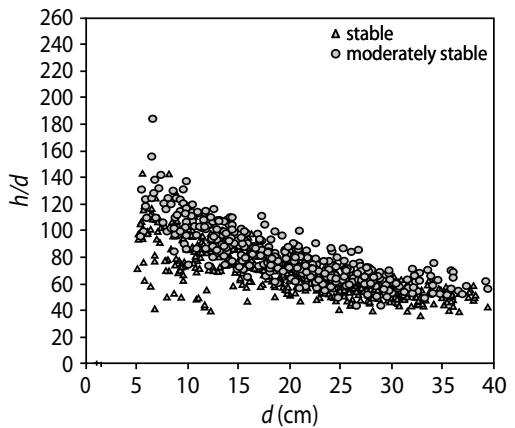

Figure 2. Municipality of Oleiros - plots in 1991, 1994 and 1996: A - stand stability classification; B - stocking - SDI by stand stability; $\mathrm{C}$ - stocking $-F_{w}$ by stand stability; D - site productivity - Sh 25 by stand stability; E - stand volume according to $d g$ by stand stability; $\mathrm{F}-\mathrm{G}$ - diameter distributions by stand mean age classes in each stand stability class; $\mathrm{H}$ - sample trees slenderness ratio; and I-J - sample trees age in 1991 plots, in 1994 plots and in 1996 plots 


\section{OPEN}

A

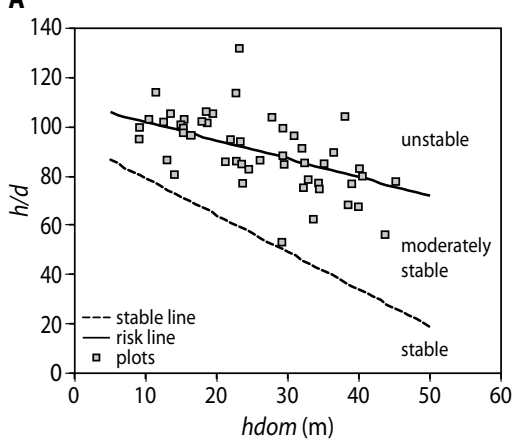

D

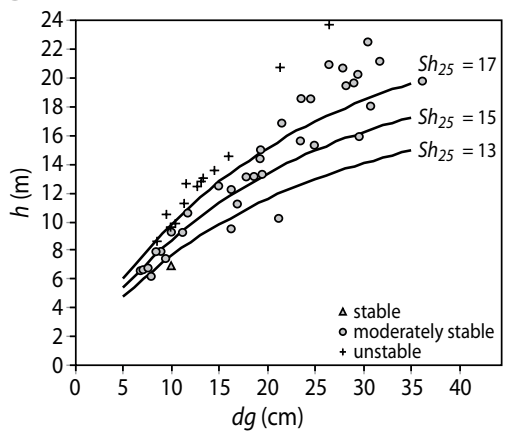

F

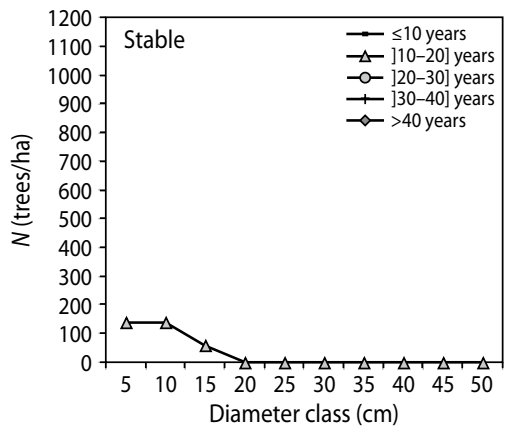

I

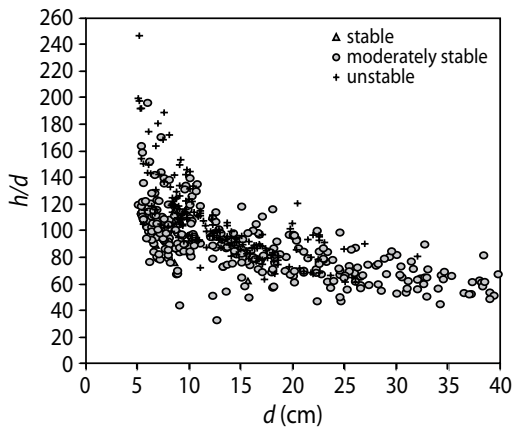

B

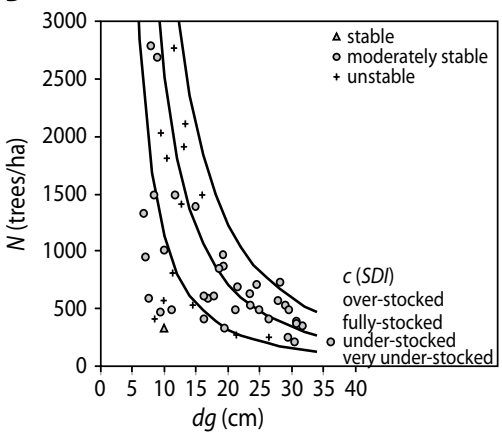

E

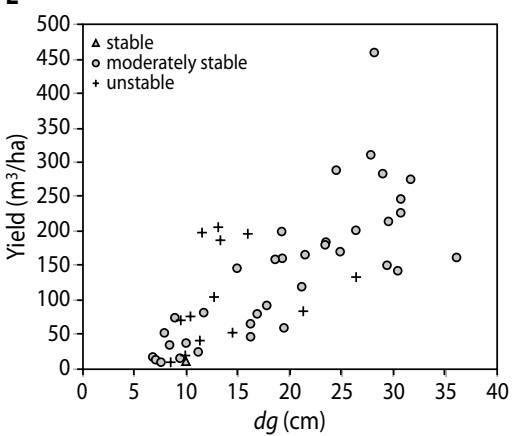

G

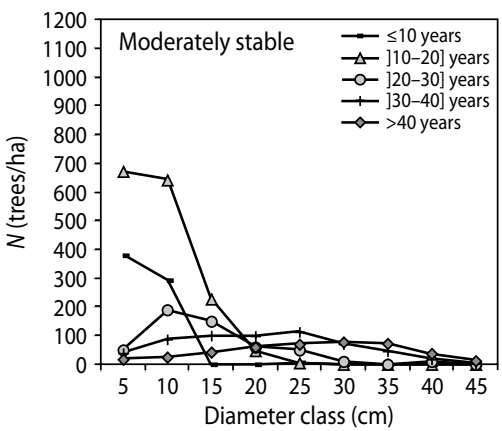

C

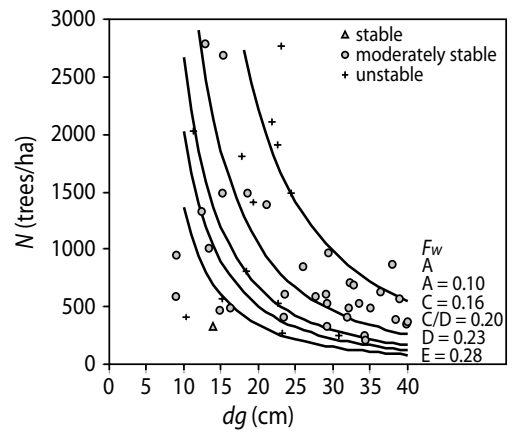

H

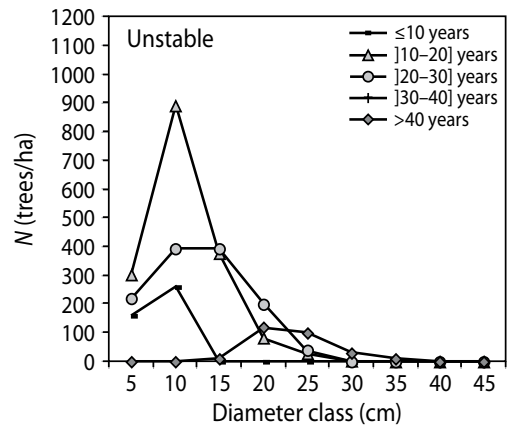

Figure 3. Locality of Sarnadas S. Simão - plots in 2007 and 2010: A - stand stability classification; B - stocking - SDI by stand stability; $\mathrm{C}-$ stocking $-F_{w}$ by stand stability; D - site productivity - Sh 25 by stand stability; E - stand volume according to $d g$ by stand stability; F-H - diameter distributions by stand mean age classes in each stand stability class; and I - sample trees slenderness ratio 
(Fig. 3F-H). The occurrence of small-diameter poles was found dependent of both age class and stability class $\left(c^{2}(3)=639.602, p\right.$-value $\left.=0\right)$. A higher incidence of small-diameter poles was observed in moderately stable stands at the age class of $\bar{t} \in] 10,20]$ years. In stable stands, small-diameter poles were only found at the class age of $\bar{t} \in] 10,20]$ years, while in unstable stands small-diameter poles were found until the class $\bar{t} \in] 20,30]$ years.

The coefficient of variation $(\mathrm{CV})$ of plot tree size variability was $59 \%$ for tree diameter variability and $68 \%$ for tree height variability. Sample trees slenderness ratio $(h / d)$ (Fig. 3I) were found to be statistically different with regard to stand stability $(F(2,494)=30.487$, $p$-value $=0.000)$. The results of the Tukey test for multiple comparisons proved that tree slenderness ratios $(h / d)$ were statistically similar in stable stands and in moderately stable stands, and statistically similar in moderately stable and in unstable stands, but statistically larger in unstable stands than in stable stands. With regards to small-diameter poles (e.g. $d \leq 12.5 \mathrm{~cm}$ ), the slenderness ratios $(h / d)$ were found to be higher in unstable stands $(h / d=124.15)$ when compared to stable stands $(h / d=87.01)$.

\section{Maritime pine stands over time (1991-1996 vs. 2007-2010)}

It was proved that no significant statistical differences (Tab. 2) were found between the data collected in 1991, 1994 and 1996 over the study area, the locality of Sarnadas S. Simão (Fig. 1B; $n=9$ ), and the rest of the data collected over the municipality of Oleiros (Fig. 1B; $n=76-9=67$ ). Thus, maritime pine stand characteristics in the municipality of Oleiros are representative of the ones in the study area, the locality of Sarnadas S. Simão, in 1991, 1994 and 1996.

The comparison of the data collected in 1991-1996 (Fig. 2; $n=76$ ) and the data collected in 2007-2010 (Fig. $3 ; n=50$ ) proved that significant statistical differences for most of the variables considered were found, with the exception of variables $N$ and $\bar{h}$ only (Tab. 2). Conversely, plot's diameter distributions in 1991-1996 (Fig. 2F-G) and in 2007-2010 (Fig. 3F-H) showed that small diameter poles were observed even in old stands.

Table 2. Comparison of stands characteristics: plots in 1991, 1992 and $1996(n=67$ versus $n=9)$ and plots in $1991-1996$ $(n=67)$ versus plots in 2007-2010 $(n=50)$

\begin{tabular}{|c|c|c|c|c|c|c|c|}
\hline \multirow[t]{2}{*}{ Variable } & \multirow[t]{2}{*}{ Symbol (units) } & \multicolumn{3}{|c|}{$\begin{array}{l}\text { Plots } 1991,1992 \text { and } 1996(n=76) \\
n=67 \text { versus } n=9\end{array}$} & \multicolumn{3}{|c|}{$\begin{array}{c}\text { Plots } 1991-1996 \text { versus plots } \\
\text { 2007-2010; } n=76 \text { versus. } n=50\end{array}$} \\
\hline & & $t$ & d.f. & $p$-value & $t$ & d.f. & $p$-value \\
\hline Number of trees per ha & $\mathrm{N}\left(\right.$ trees ha $\left.{ }^{-1}\right)$ & 0.064 & 74 & 0.949 & 0.478 & 66 & 0.634 \\
\hline Basal area per ha & $G\left(\mathrm{~m}^{2} \mathrm{ha}^{-1}\right)$ & 0.284 & 74 & 0.778 & 8.208 & 88 & $0.000 *$ \\
\hline Quadratic mean diameter & $d g(\mathrm{~cm})$ & 0.513 & 74 & 0.610 & 2.849 & 70 & $0.006^{*}$ \\
\hline Mean height & $\bar{h}(\mathrm{~m})$ & 0.214 & 74 & 0.831 & -0.042 & 69 & 0.966 \\
\hline Stand slenderness ratio & $h / d$ & -0.401 & 21 & 0.693 & -7.097 & 78 & $0.000 *$ \\
\hline Dominant diameter & ddom $(\mathrm{cm})$ & 0.799 & 74 & 0.427 & 15.174 & 124 & $0.000 *$ \\
\hline Dominant height & hdom (m) & 0.792 & 74 & 0.431 & -6.015 & 54 & $0.000 *$ \\
\hline Crown competition factor & $C C F(\%)$ & 0.250 & 74 & 0.803 & 8.227 & 87 & $0.000^{*}$ \\
\hline Stand density index & $c(S D I)$ & 0.229 & 74 & 0.820 & 8.505 & 87 & $0.000^{*}$ \\
\hline Wilson factor & $F_{w}$ & 0.093 & 74 & 0.926 & -2.577 & 78 & $0.012 *$ \\
\hline Site productivity & $S h_{25}(\mathrm{~m})$ & -0.009 & 74 & 0.993 & -5.063 & 124 & $0.000 *$ \\
\hline Site index & $S I_{35}(\mathrm{~m})$ & 1.238 & 74 & 0.220 & -13.061 & 61 & $0.000 *$ \\
\hline Total volume & $V\left(\mathrm{~m}^{3} \mathrm{ha}^{-1}\right)$ & 0.474 & 74 & 0.637 & 6.101 & 124 & $0.000 *$ \\
\hline Mean annual increment & $M A I\left(\mathrm{~m}^{3} \mathrm{ha}^{-1} \mathrm{yr}^{-1}\right)$ & 1.023 & 74 & 0.309 & 2.157 & 77 & $0.034^{*}$ \\
\hline Mean age & $\bar{t}$ (years) & -1.157 & 74 & 0.251 & 4.975 & 75 & $0.000 *$ \\
\hline
\end{tabular}

$n$ - sample size; d.f. - degrees of freedom; *p-value $<0.05$ 
Table 3. Summary statistics for maritime pine natural regeneration in the study area, the locality of Sarnadas S. Simão (plots in 2007; $n=18$ )

\begin{tabular}{|c|c|c|c|c|c|c|}
\hline \multirow{3}{*}{$\begin{array}{l}\text { Variable } \\
\text { - plots }\end{array}$} & \multirow{3}{*}{$\begin{array}{l}\text { Symbol } \\
\text { (units) }\end{array}$} & \multirow{3}{*}{$n$} & \multicolumn{4}{|c|}{ Locality of Sarnadas S. Simão } \\
\hline & & & \multicolumn{4}{|c|}{ plots $(2007)$} \\
\hline & & & $\min$. & $\max$. & mean & std. dev. \\
\hline \multicolumn{7}{|c|}{ Tall regeneration - seedlings mean height $\geq 1.30 \mathrm{~m}$} \\
\hline $\begin{array}{l}\text { Ground } \\
\text { cover }\end{array}$ & $G C(\%)$ & 6 & 10 & 30 & 18 & 7.6 \\
\hline $\begin{array}{l}\text { Number of } \\
\text { seedlings } \\
\text { per ha }\end{array}$ & $\begin{array}{l}\mathrm{N}_{\mathrm{s}}(\text { seed- } \\
\left.\text { lings ha }{ }^{-1}\right)\end{array}$ & 8 & 1,000 & 50,000 & 32,625 & $1,5519.0$ \\
\hline $\begin{array}{l}\text { Seedlings } \\
\text { mean age }\end{array}$ & $\bar{t}_{S}($ years $)$ & 8 & 3 & 4 & 4 & 0.4 \\
\hline \multicolumn{7}{|c|}{ Short regeneration - seedlings mean height $<1.30 \mathrm{~m}$} \\
\hline $\begin{array}{l}\text { Ground } \\
\text { cover }\end{array}$ & GC (\%) & 8 & 10 & 90 & 62 & 31.6 \\
\hline $\begin{array}{l}\text { Number of } \\
\text { seedlings } \\
\text { per ha }\end{array}$ & $\begin{array}{l}\mathrm{N}_{\mathrm{s}}(\text { seed- } \\
\left.\text { lings ha }{ }^{-1}\right)\end{array}$ & 10 & 300 & 30,000 & 8,442 & $10,860.1$ \\
\hline $\begin{array}{l}\text { Seedlings } \\
\text { mean age }\end{array}$ & $\bar{t}_{S}($ years $)$ & 10 & 2 & 4 & 3 & 0.6 \\
\hline
\end{tabular}

$n$ - sample size; min. - minimum; max. - maximum; std. dev. - standard deviation
However, sample tree size variability was found to be higher in 2007-2010 plots than in 1991-1996 plots. Likewise, sample tree slenderness ratios $(h / d)$ were also statistically higher in 2007-2010 than in 1991-1996 $(t(78)=-7.097, p$-value $=0.000)$.

The assessment of species regeneration over maritime pine burnt areas (Tab. 3) showed excellent levels: an average of 32,625 seedlings per hectare for tall regeneration (mean height $\geq 1.30 \mathrm{~m}$ ) with four years of age and an average of 8,445 seedlings per hectare for short regeneration (mean height $<1.30 \mathrm{~m}$ ) with three years of age. Ground cover was found higher in short regeneration plots (10 plots) than in tall regeneration plots (8 plots) as they were also covered with scrubs (e.g. Erica sp., Pterospartum sp. and Cistus sp.)

\section{Forest cover change (1990-2007)}

During the period of 1990-2007 (Fig. 4a), an enormous decrease of 'Maritime pine forest' area $(-1,131 \mathrm{ha})$ was observed. 'Agricultural areas' have also decreased (-155 ha). However, an increase of 'Maritime pine open forest' area indicates that after the 2003 wildfire, the species had the ability of regenerate a significant

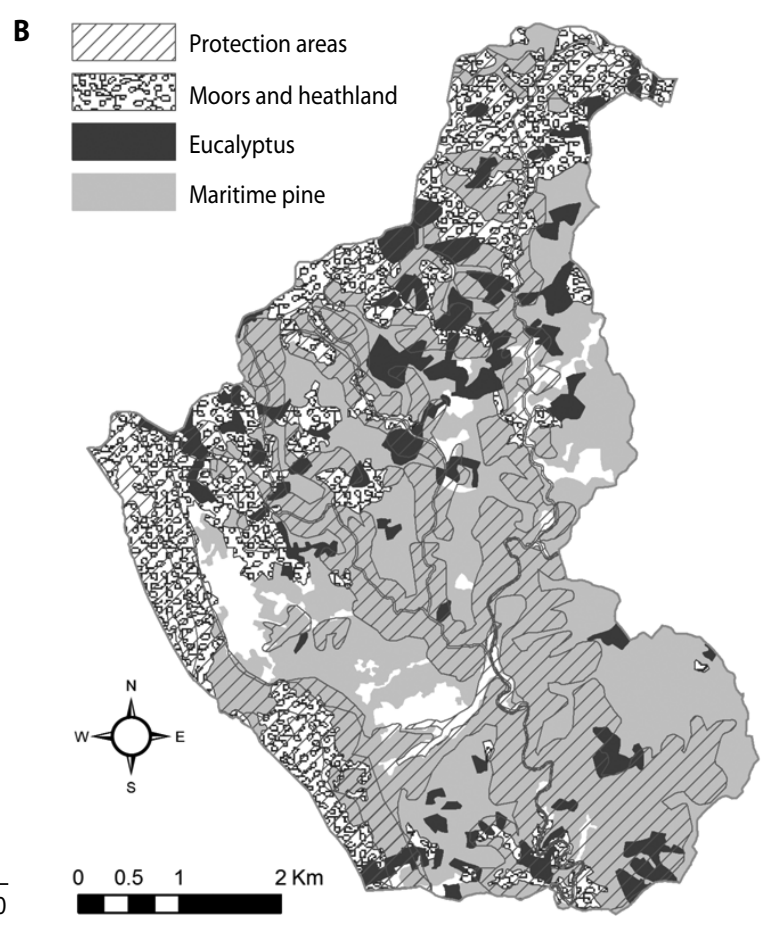

A

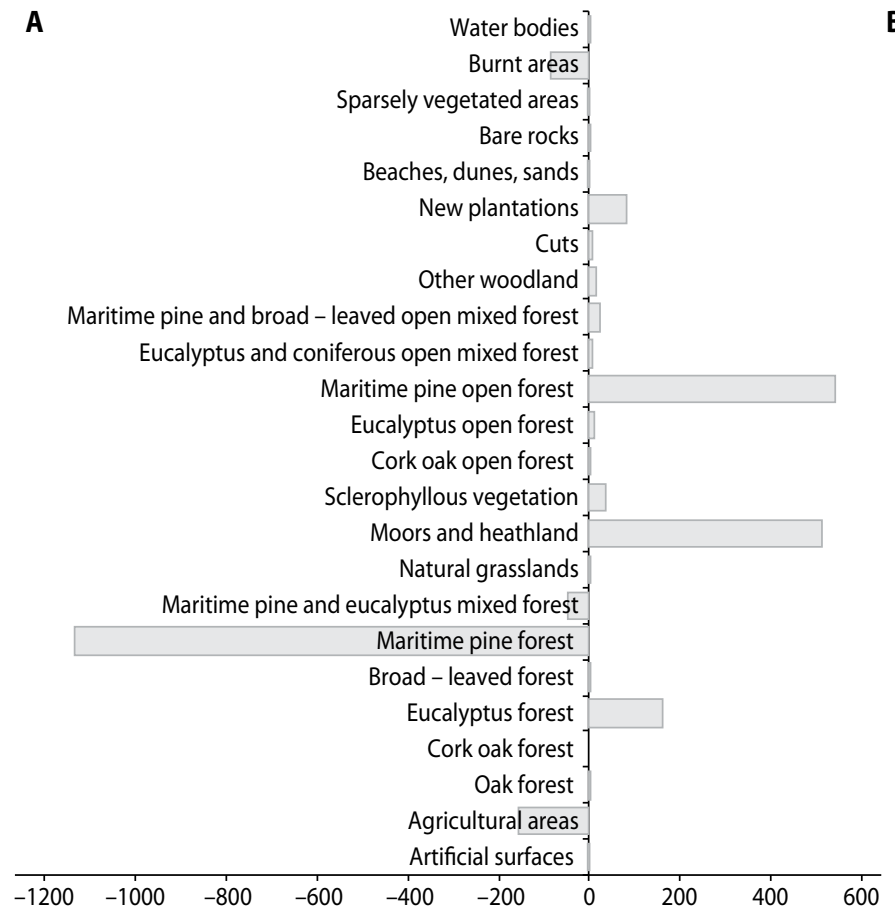

Figure 4. Locality of Sarnadas S. Simão: A - land cover gains and losses (ha) over the period of 1990-2007; B - forests and rangeland in 2007 
amount of its previous area (+542 ha). Nevertheless, 'Eucalyptus forest' area, 'New plantations' area (e.g. eucalyptus plantations) and 'Moors and heathland' area have also increased $(+162$ ha; +84 ha; +515 ha, respectively).

As a result, maritime pine species areas have decreased from $79 \%$ (2,459 ha) in 1990 to $56 \%$ (1,852 ha) in 2007. Eucalyptus species area and new plantations areas (e.g. eucalyptus plantations) have increased from $0.9 \%$ (25 ha) in 1990 to $9.5 \%$ (294 ha) in 2007. These areas were mainly found in post-burnt areas (Fig. 1C and Fig. 4A). Likewise, scrubland areas have largely increased (from $7.1 \%$ in 1990 to $23.7 \%$ in 2007). Conversely, areas of native oaks species are still practically non-existent (Fig. 4A). Most importantly, 58\% (170 ha) of eucalyptus species areas were found over protection areas (Fig. 4B).

\section{Discussion AND conclusions}

The analysis of maritime pine stand characteristics allowed to observed that in 1991, 1992 and 1994 these stands were mainly fully-stocked to over-stocked and either stable or moderately stable (no unstable stands were found). Stand slenderness was found to be higher in stands either having higher density or in higher productivity sites. Moderately stable stands proved to have higher stand volume. Stable stands of ages between 10-20 years and moderately stable stands of age between 20-30 years indicate that some type of thinning was applied. However, in stands over 30 years old, a large amount of small-diameter poles was still observed. Conversely, maritime pine stands in 2007 and 2010 were mainly under-stocked or very under-stocked and moderately stable or unstable. This improbable combination of stocking and stability indicates that an inappropriate thinning schedule and intensity was applied without having stand stability under consideration. It appears that a high intensity late thinning was applied to these unstable stands that were previously over-stocked, resulting in this under-stocked condition. Once more, a large amount of small-diameter poles was observed. Due to past growing conditions, most of these small-diameter poles have slenderness ratios above 100 . Nunes et al. (2010), when analysing Portuguese national forest inventory data in 2005 , also found that unstable plots (only 3\%) were located at the central region of Portugal, have been established by seeding or natural regeneration in high-quality sites and with no signs of silvicultural intervention, which is consistent with this study's findings.

Regarding maritime pine natural regeneration, an average of 19,190 seedlings per hectare (ranging from 300 to 50,000 ) was observed. The average seedlings age had three or four years. No signs of silvicultural intervention were found although a non-commercial thinning around 3-5 years is usually recommended in order to set stand density around 1,000 trees per hectare to avoid high trees slenderness, which may pose stand stability problems in the future (Alves et al. 2012).

Forest cover change analysis over the period of 1990 and 2007 proved that an increase of eucalyptus areas either after maritime pine areas have been burnt or after being clear-cut was observed. More importantly $58 \%$ of eucalyptus areas were established over protection areas. Despite maritime pine areas having decreased, the introduction of native oaks or other broadleaves have not yet been observed as recommended in the regional forest management plan, in which the area under study is included (DR 2006b).

In sum, the study area's trends over the past years were the following: first, the decrease of maritime pine forest areas and its management decline; second, the increase of scrubland areas; third, the increase of eucalyptus afforestation with no regard for protection areas; and fourth, the absence of native oaks or other broadleaves introduction as recommended by the state policies.

Therefore, regardless of a strong legal framework available to support forest management, this is hardly applied due to rural population ageing. For instance, the number of inhabitants in the municipality where the study area is included has decreased during the period of 1991-2011 (from 7,769 to 5,721 inhabitants that is from 16 to 12 inhabitants per $\mathrm{km}^{2}$ ). Approximately $50 \%$ of these inhabitants have more than 60 years (CMO 2015; INE 2012), which has a great impact on implementing new strategies for forest management and fire hazard mitigation.

Additionally, despite existing some FOAs and three ZIFs (e.g. ZIF Madeirã 2,723 ha; ZIF Cabeça Gorda 1,607 ha; and ZIF Álvaro 1,939 ha) in this municipality, the efforts to create a ZIF in this study area have failed. Limited motivation of these private non-industrial 
owners may be related to both this population ageing and the occurrence of the severe wildfire in 2003.

As a result, it should be expected in a near future, that abandoned forestland that is unclaimed will be considered as „land of unknown owner" and included in a public land bank to be rented (DR 2015c). In the meanwhile, the second or third generation of private forest owners are already selling this forestland. In that view, the recent afforestation law (DR 2013) is facilitating the afforestation with eucalyptus (forestland areas smaller than 2 ha), which is being observed over contiguous areas and even in protection areas. Therefore, it is argued that the need for effective field monitoring actions with respect to state forest policies implementation. Additionally, promote selective incentives is key to mobilize private non-industrial owners to achieve the goals of state forest policies.

\section{Acknowledgements}

We sincerely thank Isabele Salavessa, English teacher, for proofreading this article.

\section{References}

AFN. 2010. National Forest Inventory in Portugal. 5th National Forest Inventory 2005-2006. Final report (in Portuguese). Autoridade Florestal Nacional. http://www.icnf.pt/portal/florestas/ifn/ifn5/relatorio-final-ifn5-florestat-1. Accessed 22 May 2015.

AFN. 2012. National action program for nematode of the pine wood control - Strategy, actions and results - presentation (in Portuguese). Autoridade Florestal Nacional. http://www.icnf.pt/portal/florestas/prag-doe/ag-bn/nmp/panc-nmp-ear. Accessed 22 May 2015.

Albuquerque J. 1954. Ecological map of Portugal (in Portuguese). Ministério da Economia, Direcção Geral dos Serviços Agrícolas, Repartição de Estudos, Informação e Propaganda, Lisboa.

Alegria C. 2011a. Simulation of silvicultural scenarios and economic efficiency for maritime pine (Pinus pinaster Aiton) wood-oriented management in centre inland of Portugal. Forest Systems, 20 (2), 361-378.
Alegria C. 2011b. Modelling merchantable volumes for uneven aged maritime pine (Pinus pinaster Aiton) stands established by natural regeneration in the central Portugal. Annals of Forest Research, 54 (3), 197-214.

Alegria C., Tomé M. 2013. A tree distance-dependent growth and yield model for naturally regenerated pure uneven-aged maritime pine stands in central inland of Portugal. Annals of Forest Science, 70 (3), 261-276.

Almeida A. 1994. Maritime pine stands growth and production evaluation in the municipalities of Castelo Branco, Oleiros and Proença-a-Nova (in Portuguese). Dissertation, Instituto Politécnico de Castelo Branco - Escola Superior Agrária. http://minerva. esa.ipcb.pt/xmlui/handle/123456789/1346. Accessed 22 May 2015.

Alves A.M. 1975. General theory of productive intervention (in Portuguese). Instituto Superior de Agronomia, Lisboa.

Alves A.M., Pereira J.S., Correia A.V. 2012. Forestry. The management of forest ecosystems (in Portuguese). Fundação Calouste Gulbenkian, Lisboa.

Avery T., Burkhart H. 1983. Forest measurements. McGraw-Hill Book Company, New York.

Baptista F., Santos R. 2005. Forest owners (in Portuguese). CELTA, Oeiras.

Becquey J., Riou-Nivert P. 1987. L'existence de zones de stabilité des peuplements. Conséquences sur la gestion. Revieu Forestiére Francaise, 39, 323-334.

Carvalho P. 1992. Dendrometric studies in Pinus pinaster Aiton stands in the municiaplity of Oleiros (in Portuguese). Dissertation, Instituto Politécnico de Castelo Branco - Escola Superior Agrária. http:// minerva.esa.ipcb.pt/xmlui/handle/123456789/1286. Accessed 22 May 2015.

Castedo-Dorado F., Crecente-Campo F., Alvarez-Alvarez P., Barrio-Anta M. 2009. Development of a stand density management diagram for radiata pine stands including assessment of stand stability. Forestry, 82 (1), 1-16.

CELPA. 2014. Statistical Bulletin. Portuguese paper industry (in Portuguese). CELPA Associação da indústria papeleira Portuguesa, Lisboa.

Clutter J., Fortson J., Pienaar L., Brister G., Bailey R. 1983. Timber management. A quantitative approach. John Wiley and Sons Inc, New York. 
CMO. 2015. Forest fires defense municipal plan (in Portuguese). Câmara Municipal de Oleiros. http:// www.cm-oleiros.pt/conteudos/366/367/planomunicipal-defesa-da-floresta-contra-incendios/. Accessed 14 December 2015.

Coelho I.S. 2003. Land ownership and forest policy in Portugal (in Portuguese). Silva Lusitana, 11 (2), 185-199.

Davis L., Johnson K. 1987. Forest Management. McGraw-Hill, New York.

DGF. 2001. National Forest Inventory. 3rd Revision 1995-1998. Portugal (in Portuguese). Direcção Geral das Florestas, Lisboa.

DGT. 1990. Land cover map 1990 Portugal (in Portuguese). http://www.dgterritorio.pt/cartografia_e_geodesia/cartografia/cartografia_tematica/carta_de ocupacao_do_solo__cos_/cos__2007/. Accessed 20 March 2015.

DGT. 2007. Land cover map 2007 Portugal (in Portuguese). http://www.dgterritorio.pt/cartografia_e_geo$\mathrm{desia} /$ cartografia/cartografia_tematica/carta_de ocupacao_do_solo__cos_/cos__2007/. Accessed 20 March 2015.

Dias S.S., Ferreira A.G., Gonçalves A.C. 2008. Forest species suitability areas definition based on soil and climate characteristics (in Portuguese). Silva Lusitanica, 16, 17-35.

DR. 2006a. Ministers council resolution $\mathrm{n}^{\circ}$ 114/2006. National strategy for forests (in Portuguese). Diário da República, I Série - no 179 de 15 de setembro. http://www.dre.pt/pdf1s/2006/07/13800/50145029. pdf. Accessed 22 May 2015.

DR. 2006b. Decreet $n^{\circ} 8 / 2006$. Forest management regional plan of Pinhal Interior Sul (in Portuguese). Diário da República, I Série - nº138 de 19 de Julho. http://www.icnf.pt/portal/florestas/profs/prof-do-pinhal-interior-sul. Accessed 19 July 2015.

DR. 2013. Law Decreet $n^{\circ}$ 96/2013 de 19 de julho (in Portuguese). Diário da República, I Série $-\mathrm{n}^{\circ} 138$ de 19 de julho de 2013. http://www.icnf.pt/portal/ icnf/legisl/legislacao/2013/dec-lei-96-2013-de-19julho-d-r- DR. 2015a. Ministers council resolution $\mathrm{n}^{\mathrm{o}}$ 6-B/2015. National strategy for forests (in Portuguese). Diário da República, I Série $-\mathrm{n}^{\circ} 24$ de 4 de fevereiro 2015. http://www.icnf.pt/portal/florestas/ ppf/nova-estrategia-nacional-para-as-florestas. Accessed 22 May 2015.
DR. 2015b. Notice $\mathrm{n}^{\mathrm{o}}$ 11679/2015 - 1st revision approval of the Master Plan of Oleiros Municipality (in Portuguese).Diário da República, 2. ${ }^{\mathrm{a}}$ série $-\mathrm{N}^{\mathrm{o}}$ 200 - 13 de outubro de 2015. http://www.cm-oleiros.pt/conteudos/366/383/publicacao-pdm-oleiros-em-diario-da-republica/. Accessed 12 December 2015.

DR. 2015c. Law no 152/2015 de 14 de setembro (in Portuguese). Diário da República, I Série $-\mathrm{n}^{\circ} 179$ de 14 de setembro de 2015. http://www.icnf.pt/portal/ icnf/legisl/legislacao/2013/dec-lei-96-2013-de-19julho-d-r-138-serie-i. Accessed 22 September 2015. ESRI. 2010. ArcGIS Desktop, Version 10.1. Environmental Systems Research Institute. Washington: Inc. Reedlands.

FAO. 2013. The state of Mediterranean forests 2013. www.fao.org/docrep/017/i3226e/i3226e.pdf. Accessed 22 May 2015.

Fidalgo B., Páscoa F. 2007. The eucalyptus expansion and landscape modifications (in Portuguese). In: $\mathrm{O}$ eucaliptal em Portugal. Impactes ambientais e investigação científica (eds.: A.M. Alves, J.S. Pereira, J.M.N. Silva). ISA Press, Lisboa, Portugal, 329-354.

Godinho-Ferreira P., Azevedo A., Rego F. 2005. Forest typology map for Portugal (in Portuguese). Silva Lusitana, 13 (1), 1-34.

Huang S., Titus S. 1993. An index of site productivity for uneven-aged or mixed-species stands. Canadian Journal of Forest Research, 23 (3), 558-562.

Husch B., Miller C., Beers T. 1982. Forest mensuration. John Wiley and Sons, New York.

ICNF. 2013. IFN6 - Areas of land use and forest species in Portugal. Preliminary results (in Portuguese). Instituto da Conservação da Natureza e das Florestas. Lisboa. http://www.icnf.pt/portal/florestas/ifn/ifn6\#dad. Accessed 22 March 2014.

ICNF. 2015. National burnt areas mapping ("shapefile" format): 1990-1999; 2000-2009; 2010; and 2011 (in Portuguese). Instituto da Conservação da Natureza e Florestas. http://www.icnf.pt/portal/florestas/dfci/ inc/info-geo. Accessed 22 May 2015.

INE. 2012. Census 2011. Final results. Portugal (in Portuguese). Instituto Nacional de Estatística. http://censos.ine.pt/xportal/xmain?xpid=CENSOS \&xpgid=ine_censos_publicacao_det\&contexto= pu\&PUBLICACOESpub_boui=73212469\&PUB 
LICACOESmodo $=2 \& \operatorname{selTab}=$ tab $1 \&$ pcensos $=$ 61969554. Accessed 142 December 2015.

Jones N., Graaff J., Rodrigo I., Duarte F. 2011. Historical review of land use changes in Portugal (before and after EU integration in 1986) and their implications for land degradation and conservation, with a focus on Centro and Alentejo regions. Applied Geography, 31 (3), 1036-1048.

Krajicek J., Brinkman K., Gingrich S. 1961. Crown competition - a measure of density. Forest Science, 7, 35-42.

Loetsch F., Zöhrer F., Haller K. 1973. Forest inventory. Vol. II. BLV Verlagsgesellshaft mbH, Munchen.

Lönnstedt L. 2014. Swedish forest owners' associations: establishment and development after the 1970s. Small-Scale Forestry, 13 (4), 219-235.

Luís J., Bento J., Oliveira A. 1991. The allometric relationship in managing forest stands. The case of Pinus pinaster Ait. in Portugal (in Portuguese). In: Proceedings of the "Conference on Pinhal Bravo, Material Lenhoso e Resina” (eds.: F. Páscoa, A. Martinho, H. Santos, T. Ribeiro), 5-6 December 1991, Coimbra, 149-157.

Maroco J. 2011. Statistical analysis with SPSS Statistics (in Portuguese). $5^{\mathrm{a}}$ Edição, Report Number, Pero Pinheiro.

Martins R. 2007. Productive capacity analysis of the forest in Sarnadas de S. Simão locality, Oleiros municipality (in Portuguese). Dissertation, Instituto Politécnico de Castelo Branco - Escola Superior Agrária. http://minerva.esa.ipcb.pt/xmlui/handle/123456789/2441. Accessed 22 May 2015.

Mendes A. 2007. A history of rise and fall (in Portuguese). In: Pinhais e eucaliptais. Árvores e Florestas de Portugal nº4 (ed.: J. Silva). Público, Comunicação Social, S.A. and Fundação Luso-Americana para o Desenvolvimento, Lisboa, Portugal, 47-63.
Mestre S. 2011. Spatial modeling of maritime pine production in Sarnadas de São Simão locality (in Portuguese). Dissertation, Instituto Politécnico de Castelo Branco - Escola Superior Agrária. http://hdl. handle.net/10400.11/1189. Accessed 22 May 2015.

Nunes L., Tomé J., Tomé M. 2010. Stability of pure even-aged conifer stands in Portugal. Proceedings IUFRO Conference 2010 „Mixed and puré forests in a changing world" (eds.: D. Lopes, M. Tomé, M. Liberato, P. Soares), 6-8 October, UTAD, Vila Real, Portugal, 129.

Páscoa F., Bento J., Marques C. 1989. Wood production estimation for the period 1988/2048. Forest inventory. Maritime pine (in Portuguese). ACEL. Lisboa.

Reineke L. 1933. Perfecting a stand density index for even-aged stands. Journal of Agricultural Research, 46, 627-638.

Sarvašová Z., Zivojinovic I., Weiss G., Dobšinská Z., Drăgoi M., Gál J., Jarský V., Mizaraite D., Põllumäe P., Šálka J., Schiberna E., Šišák L., Wolfslehner B., Zalite Z., Zalitis T. 2014. Forest Owners Associations in the Central and Eastern European Region. Small-scale Forestry, 14 (2), 217-232.

Silva J.S., Sequeira E., Catry F., Aguiar C. 2007. The oppositions (in Portuguese). In: Pinhais e eucaliptais. Árvores e Florestas de Portugal nº (ed: J. Silva). Público, Comunicação Social, S.A. and Fundação Luso-Americana para o Desenvolvimento, Lisboa, Portugal, 221-259.

Sukovata L., Kolk A., Jaworski T., Plewa R. 2012. The risk of pine wilt disease in Poland. Folia Forestalia Polonica, Series A - Forestry, 54 (1), 42-47.

Vanclay J. 1994. Modelling forest growth and yield. Applications to mixed tropical forests. CAB International, Wallingford, UK.

Wilson F. 1946. Numerical expression of stocking in terms of height. Journal of Forestry, 44, 758-761. 


\section{OPEN}

Appendix 1. Equations and models for stand and/or variables evaluation

\begin{tabular}{|c|c|c|}
\hline Variable & Equation/Model & \\
\hline Crown competition factor & $C C F=\frac{25 \pi}{A} \sum_{i=1}^{n}\left(0.335229+0.171785 d_{i}\right)^{2}$ & (Eq. 1) \\
\hline Stand density index & $c(S D I)=\frac{N}{e^{(12.544-1.815 \ln (d g))}}$ & (Eq. 2) \\
\hline Wilson factor & $F_{w}=\frac{100}{h \operatorname{dom} \sqrt{0.933 N}}$ & (Eq. 3) \\
\hline Site productivity $(\mathrm{m})$ & $S h_{25}=1.3+(h-1.3) \frac{\left(1-e^{-1.1725}\right)}{\left(1-e^{-0.0469 d}\right)}$ & (Eq. 4) \\
\hline Site index & $S I_{35}=h d o m^{10^{\left(-0.307636+1.8 t^{-0.5}\right)}}$ & (Eq. 5) \\
\hline Tree total height & $h=e^{\left(-4.2759-0.4152 h d o m+3.0459 \frac{N}{1000}\right)\left(\frac{1}{d}-\frac{1}{d d o m}\right)} h d o m$ & (Eq. 6) \\
\hline Tree total volume & $v=0.00403+0.00026001 d^{2}-0.00034091 h^{2}+0.00004263 d h^{2}$ & (Eq. 7) \\
\hline
\end{tabular}

$A$ - sample plot area $\left(\mathrm{m}^{2}\right) ; d_{i}$ - individual tree diameter, over bark, at breast height (1.30 m above ground) (cm); $N$ - number of trees per hectare (trees ha-1); $d g$ - quadratic mean diameter $(\mathrm{cm}) ; h d o m$ - dominant height $(\mathrm{m}) ; h$ - tree total height $(\mathrm{m}) ; d$ - tree diameter, over bark, at breast height $(\mathrm{cm}) ; t$ - tree age (years); $d d o m$ - dominant diameter $(\mathrm{cm}) ; v$ - tree total volume, over bark $\left(\mathrm{m}^{3}\right)$. 